The European Journal of

Social and Behavioural Sciences

EJSBS

ISSN: 2301-2218 (online)

The European Journal of Social and Behavioural Sciences

EJSBS Volume VI, Issue III (e-ISSN: 2301-2218)

\title{
ABOUT THE CONTENT OF ESTONIAN AND FINNISH MUSIC TEACHERS' PEDAGOGICAL THINKING
}

\author{
Anu Sepp ${ }^{\mathrm{a} *}$, Inkeri Ruokonen ${ }^{\mathrm{a}}$, Heikki Ruismäki ${ }^{\mathrm{a}}$ \\ ${ }^{a}$ University of Helsinki, Box 8, 00014 University of Helsinki, Finland
}

\begin{abstract}
This article reflects on connections between music teachers' pedagogical thinking and music syllabi of Estonia and Finland. The intention of this article is to highlight these aspects, to find connections from the perspective of music teachers of both countries, and to analyse their music teaching practices according to the three level model of teachers' pedagogical thinking (Kansanen, 1993) through the lens of the comprehensive school music syllabi in the National Core curricula of both countries. The data for the qualitative research was collected by making interviews with 5 Estonian and 5 Finnish comprehensive school music teachers and analysed using the method of content analysis. The results indicated that music teachers' thinking in both countries stays mostly on the action level. The biggest differences occurred on the 1st thinking level, especially concerning the use of different music teaching methods and practices.
\end{abstract}

Keywords: Teacher's pedagogical thinking, music education, music teachers, music curriculum (C) 2013 Published by C-crcs. Peer-review under responsibility of Editor(s) or Guest Editor(s) of the EJSBS.

* Corresponding author.

E-mail address: anu.x.sepp@helsinki.fi 


\section{Introduction}

According to Galen Saylor et al. (1981) curriculum is a plan to guide an orderly and deliberate effort of education. The way curriculum is planned and utilized is very much influenced by value judgements concerning the nature of education and providing learning opportunities for students. The term "plan" here means an intention, an outline or means for the teachers to feel free and creative, not to be restricted or locked into a single plan. They also mention three major bases -- society, learners and knowledge -- to be considered for the curriculum planning (Galen Saylor et al., 1981).

As Elliot Eisner has put it: "Clearly, there are few issues that are more central to the experience that students have in schools than the content of the curriculum and the ways in which it is mediated" (Eisner, 1993, p. 38). Besides the content, this idea expresses the importance of the teacher as the "mediator" and important decision maker concerning the curriculum. Patrick Slattery describes the same issue as "the art and science of interpretation" being the central activity of putting a curriculum into practice (Slattery, 2006, p. 116). Therefore, the important question is raised about what and how teachers "mediate" and "interpret" the curriculum.

Estonian scholar Viive-Riina Ruus (2003) expresses that although curriculum is a normative document, teachers have the freedom to choose the amount of implementing it and decide the ways and approaches of doing so.

In his thought-provoking book, "The Tact of Teaching," Max van Manen (1991) very thoroughly describes different aspects and perspectives connected with the meaning and essence of several fundamental terms connected with curriculum, education, and teaching, including "pedagogy" and "pedagogical". He refers to pedagogy as excellence, which every educator should possess. Van Manen reminds us about the Greek origin of the word 2 and also of the fundamental idea and responsibility for the adults to give children direction, care and protection through their pedagogical action which, in its own turn, includes factual knowledge, norms, knowledge of teaching methods and philosophical orientation. He also emphasizes the essence of pedagogy that "manifests itself in the practical moment of a concrete situation", meaning "appropriate pedagogical action" (van Manen, 1991, 47). Action in itself is connected and dependent on "reflection" which is in some sense another word for "thinking" - about results in terms of goals- and which "in the field of education carries the connotation of deliberation, of making choices, of coming to decisions about alternative courses of action" (van Manen, 1991, p. 98).

The responsibility of the teacher and idea of the "teacher as a reflective practitioner" (Westbury, Hopmann, \& Riquarts, 2000) is the cornerstone of the whole German Didaktik 
https://doi.org/10.15405/ejsbs.89

eISSN: 2301-2218 / Corresponding Author: Anu Sepp

Selection \& Peer-review under responsibility of the Editors

tradition, being also the basis of European educational tradition, including Estonia and Finland. And it is the reflective character of teacher' thinking that distinguishes it from ordinary or everyday thinking.

So, without any doubt, teachers are the key figures putting the written or inacted curriculum into classroom practice keeping in mind the best possible solutions and thinking about the significance of the knowledge and skills for the students (Künzli, 2000).

\subsection{Teachers' pedagogical thinking}

The phenomenon of teacher's thinking has been widely discussed and researched by numerous scholars (Jones, 2008; Kansanen, Tirri, Meri, Krokfors, Husu, \& Jyrhämä, 2000; Munby, 1982; Shavelson \& Stern, 1981; van Manen, 1991). The teacher's thinking in an educational context is not just everyday thinking but can be referred to as pedagogical, because it has special qualities: it is carried out in surroundings where "duties and responsibilities of education need to be taken into consideration" (Toom, 2006, p. 35). Considering the above mentioned ideas, it also has to consider then the best possible learning opportunities for the students.

The phrase "pedagogical thinking"1 is referred to as "thinking according to the aims and goals stated in the curriculum" (Kansanen et al., 2000, p. 3). In educational context it also demands constant decision making, choosing between different options in the realm of certain criteria, expressed in curriculum. Kansanen et al. (2000) also underlines that "as not all criteria are stated explicitly; the teacher must therefore deduce, reflect, and elaborate when coming to a decision" (p. 3). The basis for such decisions may be influenced by several factors: a personal belief system, values, a 'school' of thought, a colleague, the socio-cultural environment, just to name a few.

Kansanen (1993) introduces a three level model of teachers' pedagogical thinking :

\footnotetext{
${ }^{1}$ Pedagogue = a watchful slave or guardian whose responsibility was to lead (agogos) the young boy (paides) to school (Van Manen, 1991, 37).
} 


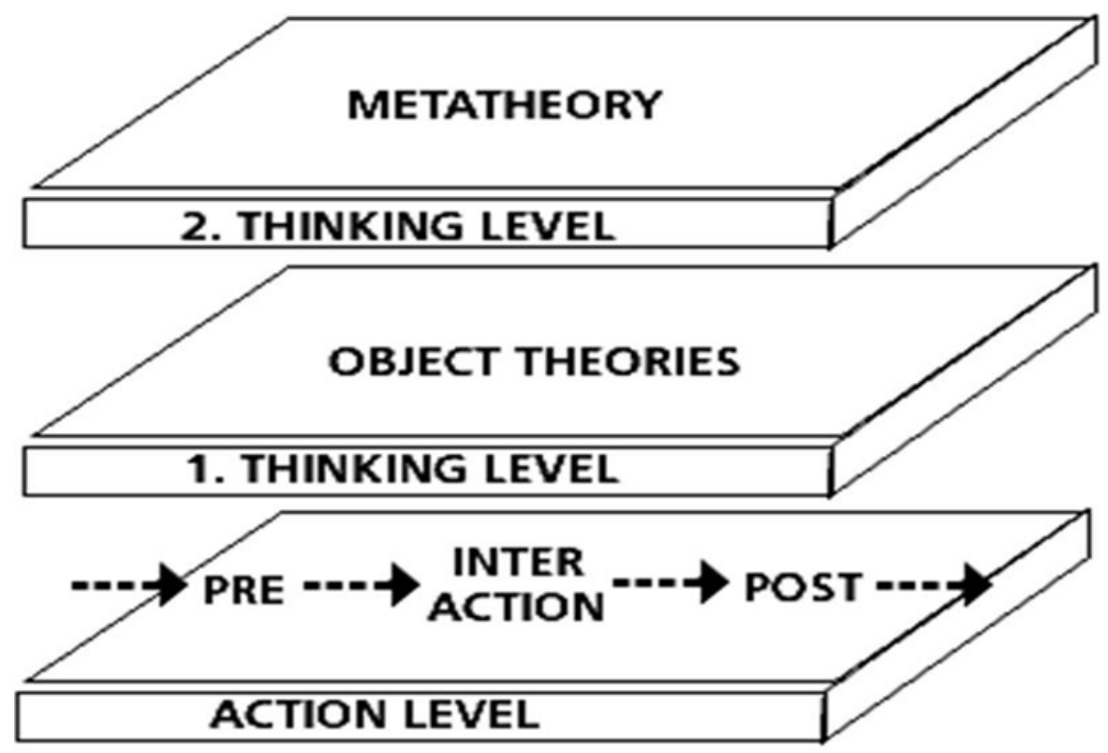

Figure 1. Pedagogical level thinking (Kansanen, 1991, 1993)

The action level concerns the teaching/learning situation in practice: its planning, implementation and evaluation. In the pre-action stage, the teacher plans the content, methods and materials to be used during the instructional process to match the comprehension of the students. Interaction is the central part, the actual teaching process during the lessons. During the interaction of teacher and students, but mainly in the stage of post-action, evaluation about the process and results already takes place.

The first thinking level, what Kansanen calls the "object theory" level, considers the didactical theories and concepts where teacher reflects critically upon the decision, reflecting on her/his own teaching practices.

The second thinking level observes the values, ethics and object theories behind the teaching practices and pedagogical interaction. It is here, where the object theories are analyzed and combined in order to create a new, perhaps even more abstract entirety (Kasnanen et al., 2000; Syrjäläinen et al., 2004).

A few possibilities exist to find out what goes on in the mind of teachers to find the factors influencing their decision making, the ways of acting in teaching-learning situations: especially using questionnaires, interviews or observation (Kansanen, 1991; 1993).

\section{Problem Statement}

The main object and goal of teachers' pedagogical thinking, characterized by purposiveness and justification of the decisions made, is pedagogical interaction (Aaltonen, 
2003), which in practice means "the content of the teaching-studying- learning process that keeps the minds of the participants on joint activities" (Kansanen et al., 2000). Accordingly, it is the content of the subject, its curricular aims and goals, together with socio-cultural context and educational traditions, as well as teacher's content, pedagogical and practical knowledge that define the certain specific features of pedagogical thinking in different subject fields. In the case of music education, the aims and goals of the music syllabus in a national (local) curriculum, educational and socio-cultural peculiarities, the traditions of music education, as well as the teacher's own music education philosophy, beliefs and values are all involved in music teachers' pedagogical thinking.

Elliott (2009) underlines that "music educators must possess both musical understanding and "educatorship" to teach effectively and develop musicianship in children (p. 172). Regelski (2009) proposes among other issues that "curriculum is part of the system of professional teaching", but it is "the teachers who create educational experience in music for their students" (p. 161). Thus, decisions made by music teachers from among various possibilities, when applying different teaching practices, shape the final means how to achieve the objectives of the music syllabus.

Table 1 shows the application of the three level model of pedagogical thinking in music education context according Syrjäläinen et al. (2004), Patrikainen (2012).

Table 1. Model of music teachers' pedagogical thinking

\begin{tabular}{ll}
\hline THINKING LEVEL & ESSENCE OF MUSIC TEACHERS' THINKING \\
\hline - & $\begin{array}{l}\text { vision of music education's task in the society and pupils' everyday } \\
\text { life } \\
\text { the ability to consider critically the traditions of music subject } \\
\text { didactics and reflect one's own teaching through this critical analysis } \\
\text { awareness about music education history, traditions, values } \\
\text { understanding about the philosophical underpinnings of music } \\
\text { education }\end{array}$ \\
\hline OBJECT THEORY LEVEL & - $\begin{array}{l}\text { the perception about the music education syllabus as part of the } \\
\text { school curriculum } \\
\text { awareness of the theoretical criteria of the music subject: objectives, } \\
\text { main concepts, formation of the content and structure in teaching - } \\
\text { learning process } \\
\text { ability to reflect on music teaching techniques, methods, approaches } \\
\text { in one's own practice }\end{array}$ \\
- $\begin{array}{l}\text { basic knowledge of music subject content and skills } \\
\text { perception of different techniques, methods and models, that are most } \\
\text { suitable for music teaching } \\
\text { idea of the musical skills of the students and about the main problems } \\
\text { connected with content learning } \\
\text { vision of the main differences between different groups and its impact } \\
\text { on the whole music teaching process } \\
\text { contextual solutions in music subject connected to content } \\
\text { prioritization in the music syllabus of national curriculum } \\
\text { ability to create suitable music material and find appropriate } \\
\text { repertoire }\end{array}$ \\
\hline
\end{tabular}


The aim of the study is to identify the pedagogical thinking of Estonian and Finnish music teachers' in terms of Kansanen's three level model of teachers' pedagogical thinking (Kansanen, 1993): to what extent are the decisions that teachers make being influenced by the state curriculum, what music teaching practices are mostly used, and what music education ideas support those practices.

\section{Research Questions}

The research questions are the following:

1.How is the music teaching process presented in teachers' pedagogical thinking?

2.What are the teaching practices most typically used to meet the objectives of the music curriculum?

3.What are the main differences and similarities in Estonian and Finnish music teachers' pedagogical thinking?

\section{Purpose of the Study}

The aim of the study is to identify the pedagogical thinking of Estonian and Finnish music teachers' in terms of Kansanen's three level model of teachers' pedagogical thinking (Kansanen, 1993): to what extent are the decisions that teachers make being influenced by the state curriculum, what music teaching practices are mostly used, and what music education ideas support those practices.

\section{Research Methods}

In order to find out music teachers' opinions about their teaching practices and research their pedagogical thinking 5 Estonian and 5 Finnish comprehensive school music teachers were interviewed during 2012. The interviewees of Finland are marked as S1, S2, S3, S4 and S5, there are 4 female teachers and 1 male teacher. They all have studied at different educational institutions (Lapi University, Oulu University, Tampere University, Sibelius Academy - all MA, and Rauma Teachers' College) and have slightly different educational level: 2 of them are music teachers and 3 are class teachers with music teacher qualification.

The interviewees of Estonia are marked E1, E2, E3, E4 and E5, they are all female music teachers, but have a different educational background: three of them graduated from music college first (one as piano teacher and choir conductor, one as choir conductor and solfege teacher, one as choir conductor and piano teacher), continued studying in Estonian 
Academy of Music and Drama and graduated as music teachers (MA). Two of them studied at Estonian Academy of Music and Drama and graduated as music teachers (MA).

The data were transcribed and analyzed qualitatively by using content analysis (Cohen, Manion, \& Morrison, 2007). Hsieh and Shannon (2005) indicate and identify three distinct approaches of content analysis: conventional, directed, summative (Hsieh \& Shannon, 2005). The approach used in this research is directed approach as it relays on an existing theoretical model of teachers' pedagogical thinking by Kansanen.

\section{Findings}

Although every teacher is a unique personality with his/ her individual and subjective way of thinking, the analysis revealed several similar aspects at all the three thinking levels as well as remarkable differences. The same inclination could be observed when comparing the results of Estonia and Finland.

\subsection{Action level thinking}

\subsubsection{Music teaching practices}

The topic music teachers mentioned most concerned music teaching practices. The most frequently used music practices were singing and playing an instrument, although also music listening, theory learning were mentioned. The choice of music practices used depends mostly on the students but also on the personality of the teacher.

S3: There are so many music practices to be used: singing, listening, playing an instrument, finding connections between one's life and music [.....] and I think also the understanding of theory is important -that's where the connection with playing and singing occurs.

S4: Nowadays there are worries that Finns don't sing enough. And the trouble is that in music lessons there is not enough singing either. Singing is "in contempt". [...] In my classes we play the recorder at grades 2-6. I find it very good, especially to read the music and have one's own instrument.[....] At the beginning some would say that "recorder is stupid", but when they hear how wonderful it sounds when we play in voices, they are thrilled. [...] We don't compose or improvise and musical movement is also of less importance. We don't compose or improvise and musical movement is also of less importance.

S5: I start my lessons very often with music listening, it depends on the class, of course. I believethis also develops the musical taste in pupils. 
S1: Music lesson differs in a good sense from ordinary hard work. It is like a breathing space in an ordinary school day.

E3: Yes, we also play the recorder, in the $1^{\text {st }}$ grade-those little hands are so tiny, it is really complicated, but children like it. But the guitars... our school doesn't have the instruments. I think that most important still is singing, at least in comprehensive school part. And of course all those musical practices: playing instruments, musical movement, creative activities, going to concerts ... everything is actually important and interesting. [...] For the pupils music lesson is different thanthe other lessons, I think: you don't have to write so much, you can feel more free, can be more creative and can sing- this is important for all age groups.

E1: ...pupils LIKE to sing and they are sometimes annoyed, saying:"Why do we have to learn all this staff... lets better sing!'”. Number one is singing, but actually I use them all... we use relative match pitch, ... all those practices are I want to say connected... integrated.

E4: We have the instruments and recorders... and also guitars for the stage III. And singing, this is of course like a MUST, in every stage, depending only how many voices. It is important that pupils want to sing, participate in the Song festival both, as a singer or as the audience [....]...And they really like to come to the music lesson, but of course, it is the initiative ...it depends on the teacher.... and I think the teacher to guide the pupils to continue, to move on, starting at school with the recorder and then later learning other instruments.

E5: I try to use all the musical practices, to like... synthesize, combine them. But, yes, perhaps singing is still maybe number one.

\subsubsection{Lack of resources}

Other repeated themes were the lack of resources (small amount of music lessons as well as instruments, technology), too big groups for learning instruments.

S4: The number of lessons changes...but is still too small. 2 lessons are enough, but 1 is too little.Can you imagine that you have to play, sing, listen, learn the history and theory --- all within 45minutes!!! You cannot do it! There should be at least 2 lessons per week. Pupils like music lessons!! S5: Everything depends on the local conditions but I think music needs more resources- more instruments and also more lessons.

S3: There is onlyl music lesson per week in grades 1 and 2 -it is TOO LITTLE!! And there are so many things to do! There are 2 lessons at grades 3-5 and 
this is much better [...]. There areproblems: I think our school is lucky to have enough instruments but that is not so in every school. .... The number of students is too big. I think the arts also deserve the possibility to work in smaller groups. It is a big challenge for the teacher to organize and get everything done and everybody participate, to guide everybody who need guidance.

S2: When we think about all the neuropsychological research and the wide possibilities there are to develop the abstract thinking with the help of artsthen ... yes... it is not enough. It is simply not enough!!

E1: the number of lessons is really too small, one just cannot fulfil all the things written in the syllabus. The only thing that... well... the teacher has to take into account the class and the pupils and somehow "mend" it to the needs of the class.. then it may be possible.

E2: in our school...big problem is the money... there are no instruments, no Orff instruments. yes, we use body-percussion..but it is difficult to work.... difficult to make interesting lessons.

E1: lately the finances are real problem- there's not enough money even to buy books and workbooks for music - all the money is in one big cattle...it feel a waste of time to even ask for it... it's like hitting one's head to the wall.... The differences are SO big between different schools... I have talked to many colleagues .. some have everything, some have got nothing... depends so muschupon the teacher, the headmaster, how big is the school...

\subsubsection{Music teaching materials}

The topic of music teaching materials was also presented by music teachers but there was noticeably a different viewpoint between Estonian and Finnish teachers. Estonian teachers relied more on music books, workbooks and "ready-made" teaching materials than their Finnish colleagues.

E1: I use music books a lot to plan my teaching, not everything and all, but still...right now I'm verymuch dependent on music schoolbooks.

E2: I look the workbooks, we don't have them enough, but I make copies.

S2: I don't use books because these are too much structured and start to "mold" the teaching. I try to "produce" the teaching materials myself, sometimes I use some songs from music books.

S1: ...I don't follow any particular music book...First there is an idea what kind of a song I need and then I start looking for it, using different books. 
S5: I don't use any music books, my teaching is based on the project teaching idea. My own view is that there are no "musts" - nobody "must" sing alone or sing at all if one doesn't want to. In music making there are so many possibilities that everybody can choose and find something of interest: listening, playing, singing.

\subsubsection{Assessment of music subject}

Estonian music teachers mentioned also the problem of assessment in music subject. E1: I don't use or do any tests in music any more. This doesn't make sense: they just learn by heart and don't understand and then they forget. It makes much more sense to make group works and use active learning techniques- they have to think and they learn much more, I think.

E3: The biggest problem for me is the assessment: correction of the tests.

\subsubsection{Insufficient musical training}

The Finnish teachers brought up the insufficient time for music studies in class teachers' training as well as not enough in-service training for music subject.

S5: I can track down the differences between schools as the pupils come to me after lower secondary school - there are big differences in what they know and can do. In some school the teaching is very poor, depending on the possibilities of the school but also on the skills of the teacher. There are some class teachers who can play no instruments- it is a pity when a teacher has to teach music with the help of CDs only. There are usually no music teachers at lower secondary school, so the level may be very uneven.

S1: I don't use any special method-I think I'm not prepared enough as our schooling had not enough music theory and pedagogy

S2: In my school the class teachers appreciate very much that there is a music subject teacher to teach music also at lower grades. In Finland the class teacher's training does not contain enough music and the teachers are therefore in a poor position.

S4: There is not enough in-service training for music teachers, this gives new ideas and energy. It isall about computers nowadays, the arts are somehow left aside.

S1: I think there is not enough in-service training for the teachers of music. In our county it is really poor compared with several others. I think there would be participants if only somebody arranged them. 


\subsubsection{Connections between action and object theory level.}

It was interesting to notice several connections between the action and the object theory level.

E2: I think that instrument playing is very good in the new NC.

E3: But I really want to say that there is much more joy, really. ALL my students are really so nice, simply all are wonderful kids, everybody likes music, so much joy.

E4: I also think and find that there is much more positive things, pupils want to come to the lesson and they often surprise so nicely, sometimes I ' $m$ really tired after a long day's work but the next day... it brings usually so much joy and fun. And this is so wonderful.

S3: There are so many moments in music lessons that really pay back the hard work, so wonderfulis the feeling of success. This makes the day sometimes.

\subsection{Object level thinking}

\subsubsection{Choice of music practices and students' development}

Several interviewees mentioned the connections between the choice of music teaching practices and the age or developmental level of the students.

S2: It depends on the grade level - the general idea is that the younger the pupils, the more we "do", meaning do with the help of the body. The 3.grader has to learn more using kinaesthetic and motoric possibilities than the 9.grader. The 9.graders can understand the abstract thinking use it in their thinking. [....] Actually I use everything: singing, playing an instrument, movement, listening, elementary theory, music history, composing, improvisation, concert going. I try to mix the cognitive with skills, with "doing". First we "do" and then we think what have we "done". E4: Well, the smaller the child the more.... you like DO, start with a song, then you can add instruments.... and then there are concerts at the school where pupils can attend. They have a listening task to fulfil and they are really attentive listeners. They want to get a good mark also! [....] ...There is also improvisation, when we have started with runic songs and they make their own melody and text. But we also use computers for putting down what they have created, there is Note flight we use. E5: The aim is to show my pupils that music is interesting and that EVERYONE is capable to create and make music... the teamwork is important: those who are more talented help the oneswho are not so gifted in music.

S3: Although the music syllabus is at the back of my work, I noticed that the classes 
are very different - you cannot use the same approach with everybody. I'm lucky to have much experience both in work and music to solve such problems.

\subsubsection{Music teaching approaches/methods}

The issue of music teaching approaches/methods revealed considerable differences between Estonian and Finnish music teaching.

S5: I am sorry to say that I don't know the methods. I think Orff approach would be good in grades 7-9, but I have only an idea what it actually is. Should participate in a course to bring back what was learned at the university.

S4: I don't use any methods - I don't consider myself at home with the methods. Perhaps there are some good (methods)....I don't know.

S3: I somehow feel that Orff ideas have the closest connection with my teaching....but actually I

...mix methods.

E1: Kodaly and relative match pitch is good, especially in the elementary level. The intonation is much better, the models help to sing. Later it starts to ...maybe to limit a little, especially when you teach instruments. I think that the use of methods, for instance relative match pitch depends so much on the teacher... I have some problems as I have learned using other system myself and this is sometimes very difficult.

E5: Well, the basis is Päts-Kaljuste approach, yes, and I also use Orff elements, but ...it differs, I change it according to the pupils, what is suitable and best for them.

E4: I really support the relative pitch match. At the beginning, as I myself studies music using absolute system, I didn't like this JO-LE-MI system. But now, later, in my work... so much proof that it really helps children... [....]...I REALLY support that system now. And when it comes to instruments, we use $a-b-c$ and this is then easier, they don't mix and fuss with the names then.

S2: Well, my own ideas of music education have much to do with Elliott's paraxial, pragmaticviews. [....]I do not like Kodaly-as I have studied "under" this system myself, this makes me sick!!

\subsubsection{Music syllabus and curriculum}

Teachers had various opinions about the music syllabi of the National Curriculum. These attitudes also differed according to the countries.

S1: The music syllabus in the National Curriculum (NC) is not of much help in 
everyday school life as they are so wide. These are more like beautiful ideas that should be accomplished.

S5: I have to confess that I don't know much about the music syllabus in the National Curriculum. We went through it during the studies at the university but afterwards.... I rely on my own experiences rather than anything else.

S3: Well, at least once a year, in autumn when I get the grades I am going to teach and start to planthe next year.... then I have a look into the National Curriculum. The municipality curriculum is much more exact and specific so we have nothing to add at school and this has to be followed

S4: I do not remember exactly but I think our school curriculum is the same as municipality. This is the "must", our bible, you can always add something but what's in there, has to be done..... Don't know anything about the National Curriculum, I think it is somehow "dead" already long ago. The only problem is when a child changes the school from one municipality to another - then there might be problems.

S2: I think the problem in Finland is that usually there is only one music teacher at a school and when this teacher makes a music curriculum-it is like he/she makes it for her/himself and these are then the teacher's personal views on music subject. So for me the question is about the school curriculum - it's more like the teacher's personal curriculum or teaching plan. That means there should be some kind of general, nationwide line that would be followed. Perhaps there has been too much "room for maneuver" in the National Curriculum. The content for my own teaching is taken from the music syllabus of the National Curriculum. But as I am a musician and I know what music means to people, I try to apply it to the "real life", outside the school. [...] I keep in mind music as something one can enjoy in free time.

E1: the general part of NC is closer to "real life" than in the previous NC one.... But of course, the music syllabus is more important, I think. [...] I think that the personality of the teacher is the key question: the teacher who blindly follows the music syllabus can make the music lesson a nightmare and nobody actually gains through such a teaching... The teacher has to make wise decisions and choose what is appropriate for the pupils.

E4: the music syllabus is very familiar, I have read it thoroughly and I know all the content and goals and aims. ....Yea... well...it is...good and wonderful ideas, but really hard to accomplish, really difficult to practise all of it. 
E5: I don't follow the music syllabus so exactly, meaning "point to point" and I make my choices...I don't think that you have to teach EVERY SINGLE thing. It's important what you stress and turn attention to: some things you just introduce and some themes teach more thoroughly.

\subsubsection{Reflecting on one's teaching practice}

Teachers had different ideas and routines about reflecting on their practices.

S4: At least once a day I go through my teaching. It is important. Especially the 1st grade for me, atthe moment.

S2: Actually, it takes me an hour to go home from work and usually I think about what happened during the day: what was good, what didn't work at all, what can be done better...

E3: I reflect at the end of the term, during the holiday. During the school day... there is no time... really I have sometimes even no time to leave the classroom: somebody comes and asks smt., we have a practice with smb., I put all the necessary things and look up.... there's no time during the school day...

E4: I plan more detailed one term at a time... usually there's a concert or an occasion... During theschoolday....no time, no time at all to reflect.

\subsubsection{School curriculum, status of music subject, connections with metatheory level}

The perception of music syllabus as part of school curriculum differed widely, depending mostly on theleadership of the school. Several teachers thought that as a whole, music subject should have a higher status. Teachers recognized music as a subject of great importance in pupils' overall development and it is seen in a much wider context.

S1: Nobody makes pupils to choose between math or physics or maths and mother language. But if one has to choose between music and drawing, the result is that the other is automatically omitted. So, some subjects are for everybody and some are the ones you have to choose between. This puts them into an unequal position. But it would be so important for general education sake to learn them at school. That's what I think.

S4: Music should not by any mean be a "second quality" subject. But from the other side, if the teacher is not professional enough,... it does not do any credit to music at school.

S5: I have participated in doing the school curriculum for music and this is like project based -the idea is that every now and then we produce something: a 
musical, a cd, a concert. And this is every year [...]. we write down the general objectives, but nothing very exact.

E4: Our headmaster really supports music teaching in every possible way, especially with instruments. There are only problems with rooms: we have a really old schoolhouse and there is simply lack of space. I think that music HAS to be in school- the whole school would be much poorer and it is about the culture as a whole.

E3: Well, our school board also supports, we have enough instruments... but...yes...the problem is with not having enough space [...]. It is the knowledge about culture and traditions, and the possibility to integrate different subjects in music lesson-I think music as a subject is important.

E5: in our school music is considered as a subject really, not as a ..well, an out of class activity as I know in some schools. Sorry to say that [....].

E1: the board of the school doesn't care very much for music, yes, if smt. is good then it is OK... Well our headmaster is sports-fan, and that is the sphere he supports, not the arts [...]. When there'smuch singing in the school, it gives another "breathing" to the whole school. I think most importantis the fact that children wait for the lesson ... that's what matters.

\subsection{Metatheory level thinking}

The metatheory level was profoundly presented in music teachers' opinions.

\subsubsection{Pupils' personality and everyday life}

The importance of music education as a significant and influential factor on pupils' personality and development in the totality of teaching was mentioned repeatedly.

S1: For the student the most important are the experiences of success. And when I notice....well, this child is so talented and I can tell this to the parents in case they don't know it... and the.. if music becomes as an hobby. This feels good.

S4: Pupils who don't attend special music school and haven't played any instruments... when such a kid suddenly becomes interested in music, gets the feeling of success...this is what matters. It is not the mark but that experience. Music as a hobby is something reasonable to do for the child.... Music has the power.

S5: I think music gives self confidence and trust, also moments of joy and feeling of success [...]. Some pupils have got the "infection" of music as a life-long hobby 
from music lessons at school [...]. And this doesn't have to be only singing or playing, but also enjoying music.

E3: It helps to develop the whole personality, to see the connections, to develop the musical taste and expand the understanding about music. Those children who sing in choir - I believe that they cannot act badly- singing makes a better person ....

S1: Music is present in everybody's life in all stages of life...... General music education shouldgive the basis... should help to find the style you like and are fond of. The task of the school musicis to "spread out the fan", from where one can find one's one "story", that already would be agreat thing.

E4: My main objective is that pupils would start to love music! [....]...Playing an instrument makes every human being beautiful!. When a pupil is interested in playing an instrument, she or he has no time to hang around in those awful shopping centres and has no time to do evil- this is my main goal!

\subsubsection{Source of joy and happiness}

There were numerous indications about the importance of music as source of joy and happiness, and also stability.

S3: The most important thing is the joy that a child gets through playing and singing. Even if one cannot sing, one can still participate. The emotional side is very important [....]. Music has always given me strength. I try to give the same feeling to the pupils .... to bring the joy although it is not always easy and fun.... one has to work for that ...sometimes real hard. But when you succeed the feeling of happiness is wonderful!

E1: When you understand and see that music has somehow touched them, even the noisiest boys and they want to listen and become interested in music... that is something you cannot describe in words. It has touched them and this is the most important thing.

S2: There has to be an understanding of "good life" in all educational matters. And what role do the arts subjects play in this understanding. You cannot measure it in numbers. It is much more, a very subjective experience. Life is not only accomplishment, there have to be joy and meaning, understanding of one's own "self" - that is where the arts have great chance- to develop the understanding of oneself and society. 


\subsubsection{Socio-cultural status of music and music education}

The socio-cultural status of music and music education were repeatedly mentioned. E1: The important thing is that if the human being has feelings and can notice beauty around ... the whole society is then better. I think in Estonia things are more or less OK... we have quite good music education... yes there are some problems but as a whole things are good.

\subsubsection{Metatheory level thinking}

The metatheory level was profoundly presented in music teachers' opinions.

\subsubsection{Pupils' personality and everyday life}

The importance of music education as a significant and influential factor on pupils' personality and development in the totality of teaching was mentioned repeatedly.

S1: For the student the most important are the experiences of success. And when I notice.... well, this child is so talented and I can tell this to the parents in case they don't know it... and the. if music becomes as an hobby. This feels good.

S4: Pupils who don't attend special music school and haven't played any instruments... when sucha kid suddenly becomes interested in music, gets the feeling of success...this is what matters. It is not the mark but that experience. Music as a hobby is something reasonable to do for the child.... Music has the power.

S5: I think music gives self confidence and trust, also moments of joy and feeling of success. [...] Some pupils have got the "infection” of music as a life-long hobby from music lessons at school [...]. And this doesn't have to be only singing or playing, but also enjoying music.

E3: It helps to develop the whole personality, to see the connections, to develop the musical taste and expand the understanding about music. Those children who sing in choir - I believe that they cannot act badly- singing makes a better person ....

S1: Music is present in everybody's life in all stages of life...... General music education shouldgive the basis... should help to find the style you like and are fond of. The task of the school musicis to "spread out the fan", from where one can find one's one "story", that already would be agreat thing.

E4: My main objective is that pupils would start to love music! [....]...Playing an instrument makes every human being beautiful!. When a pupil is interested in playing an instrument, she or he has no time to hang around in those awful shopping centres and has no time to do evil- this is my main goal! 


\subsubsection{Source of joy and happiness}

There were numerous indications about the importance of music as source of joy and happiness, and also stability.

S3: The most important thing is the joy that a child gets through playing and singing. Even if one cannot sing, one can still participate. The emotional side is very important. [....] Music has always given me strength. I try to give the same feeling to the pupils....to bring the joy although it is not always easy and fun.... one has to work for that ...sometimes real hard. But when you succeed the feeling of happiness is wonderful!

E1: When you understand and see that music has somehow touched them, even the noisiest boys and they want to listen and become interested in music... that is something you cannot describe in words. It has touched them and this is the most important thing.

S2: There has to be an understanding of "good life" in all educational matters. And what role do the arts subjects play in this understanding. You cannot measure it in numbers. It is much more, a very subjective experience. Life is not only accomplishment, there have to be joy and meaning, understanding of one's own "self" - that is where the arts have great chance- to develop the understanding of oneself and society.

\subsubsection{Socio-cultural status of music and music education}

The socio-cultural status of music and music education were repeatedly mentioned.

E1: The important thing is that if the human being has feelings and can notice beauty around ... the whole society is then better. I think in Estonia things are more or less OK...we have quite good music education... yes there are some problems but as a whole things are good.

S3: ...it is so important to do smt in group. And in music there is so much doing together. And it doesn't work if you don't take into account the others....just maybe one glance is important. This feeling and understanding is crucial.

S4: They claim that choir singers live longer and are happier. I think that the community, the feeling of belonging and being part of something is the matter that counts. I wish my students to get the same joy and happiness I have practiced during my long choir singing career.

S3: There's this social aspect in it. For the pupils the importance is the feeling of 
success [...] and to do things together. It is sometimes very time - and work consuming. Music may be a very personal matter especially singing may be very difficult ...to overcome one's fears.

S3: I think about music as part of culture...so important that pupils learn to appreciate music aspart of culture. So that if they find that the things we learned at school are there, in the music they hear and they make the connection.

Estonian teachers repeatedly mentioned the socio-cultural importance of Song festivals.

E1: The meaning and participation in Song Festivals, that is really important. ...There was so much workat the beginning and children didn't want to participate in the choir at first and I had to explain so music.

...But when the festival was over and they came, all one by one to hug me and said thank you, teacher that you brought us here... this is the real award for this work.

E3: Song festivals ---it is important that pupils participate in song festivals- in my school it was the first time that we participated and those who did were simply fascinated! The feeling is very different when you participate, otherwise it is just speech...

E-4: In our school choir singing is extremely popular, the choirs are really big: boys' choir -about 46 participants, doddlers' choir - about 55-60 participants, mixed choir -even 80 participants.I am sorry to say that there could be even more in boys' choir, for example, but I am alone and I just have not enough strength to deal with so many boys, you know.

\subsubsection{Philosophical underpinnings}

Music teachers also comprised interesting connections between music education and their own philosophicalperceptions.

S2: Well, I think music history should be taught at music lessons also as we are educating future humans who have to get along in life and society. To my mind one of the assumptions to this is the understanding about why we are here, where we have come from. This is why we have to go through history- to make future plans and predict the possibilities. [....] The same is true about music history-we can predict what trends are coming, find the meaning of music to oneself. If we take into consideration only contemporary music, the moment where we are now, one cannot understand, why we are here where we are... well... the proportions have to be 
right, of course. Andwhat is most important - the teacher has to make connections with the present day.

E-5: The objectives and aims- there are so many!! Music is all around us, it is connected with so many other things in our world... it's like one piece of a big puzzle.

E2: I think that when the child goes home and wants to think about music, searches and finds more music... these lessons have been good.

E3: the main aim is to open the eyes and give a wider perspective, and also to value culture and especially to respect the culture of other nations. [....]... so that both cultures would survive and there would be no hostility.

E4: ... And they really like to come to the music lesson, but of course, it is the initiative ...it depends on the teacher.... and I think the teacher to guide the pupils to continue, to move on, starting at school with the recorder and then later learning other instruments.

The main themes that occurred as the analysis results of Estonian and Finnish music teachers' pedagogical thinking are described in table 2 .

Table 2. Pedagogical thinking levels according to Estonian and Finnish music teachers' responses

\begin{tabular}{|c|c|}
\hline $\begin{array}{l}\text { Pedagogical } \\
\text { thinking level }\end{array}$ & Summary of music teachers' responses \\
\hline Metatheory level & $\begin{array}{l}\text { Socio-cultural aspects: tolerance towards different cultures; treasuring } \\
\text { and transferring cultural heritage (the phenomenon of Song festivals in } \\
\text { Estonia); influence on social relationships in society; understanding the } \\
\text { differences with the help of music; } \\
\text { Development of a personality: creativity, joy of music making (especially } \\
\text { singing), intelligence, cultural versatility, harmony and balance, } \\
\text { acknowledgement of common values, development of personalities who } \\
\text { love music; feeling of success; identity building; source of self-confidence; } \\
\text { experience of "good feeling"; finding the music style one likes; } \\
\text { Aspects of music education value, traditions, history: music as a source of } \\
\text { stability; the importance of arts in general education; } \\
\text { Aspects of (music education philosophy): ideas of paraxial music } \\
\text { education; the meaning/influence of music to "good life". }\end{array}$ \\
\hline $\begin{array}{l}\text { Object theory } \\
\text { level }\end{array}$ & $\begin{array}{l}\text { Theoretical criteria of music subject ( objectives, main concepts, } \\
\text { formation of content, structure in teaching-learning process): } \\
\text { knowledge about the national curricula and music syllabi; } \\
\text { Reflections on one's own practice (techniques, methods, models etc): the } \\
\text { music teaching ideas of Riho Päts; Carl Orff pedagogy; relative } \\
\text { solmization method of Zoltan Kodaly. } \\
\text { Perception of music syllabus as part of school curriculum: connections } \\
\text { and influence of school leadership and music education; status of music } \\
\text { subject. }\end{array}$ \\
\hline
\end{tabular}




\begin{tabular}{l|l}
\hline & Instructional process (musical activities in the lessons and extra-curricular \\
events), especially musical activities (singing, music listening, playing an & instrument, general musical knowledge, elementary musical literacy, \\
& musical movement, improvisation and composing, integration and holistic \\
creativity, co-operation with other art subjects and field trips: attend \\
concerts, performances, meeting musicians); working environment (lack of \\
instruments, not enough space); \\
Basic knowledge of content and skills, perception of techniques, methods, \\
models: differences between knowledge and use of methods, approaches of \\
music education \\
Musical skills of students, impact on teaching: the choice of music \\
teaching practices according to the age or developmental level of the \\
students; \\
Contextual solutions in content prioritization; material and repertoire for \\
music teaching: the use of music books-workbooks, searching - creating \\
own teaching materials.
\end{tabular}

\subsection{Additional themes}

Finnish music teachers mentioned problems with music teacher education and inservice training.

S4: I still wish that pupils could get the best experience in music and I think that class teacher doesn't always have enough musical education. There is not enough music in class teacher training. There is not enough in-service training for music teachers, this gives new ideas and energy. It is all about computers nowadays, the arts are somehow left aside.

S5: I am sorry to say that I don't know the methods. I think Orff approach would be good in grades 7-9, but I have only ideas what it actually is. Should participate in a course to bring back what waslearned at the university.

S5: I think most of the in-service courses are planned for lower classes, nothing for upper secondary or high school- wish there were more. I have the music knowledge still quite $O K$, thesedon't interest me much where there's band or free accompaniment ...

S5: I can track down the differences between schools as the pupils come to me after lower secondary school - there are big differences in what they know and can do. In some school the teaching is very poor, depending on the possibilities of the school but also on the skills of the teacher. There are some class teachers who can play no instruments- it is a pity when a teacher has to teach music with the help of CDs only. There are usually no music teachers at lower secondary school, so the level may be very uneven. 
S2: In my school the class teachers appreciate very much that there is a music subject teacher to teach music also at lower grades. In Finland the class teacher's training does not contain enough music and the teachers are therefore in a poor position.

Specific problems that occurred in the interviews with Estonian teachers were connected with the Russian culture and also the connections between music education and home environment.

E3: As to the different approaches, yes I use them, mostly Orff. But the relative pitch match... it is sooo difficult with Russian songs - the melody is so difficult, almost impossible to sing in relative system. So few songs that I can really use.

E1: Children come to school together with their home background - that affects a lot! So, the NCplans may be impossible to fulfil, also because of the situation at home.

E1: the instruments... yes.. .it is very good but the number of lessons is not enough.. only if they getinterested and would like to start learning individually in music schools.. but not all the parents.. actually very many families don't have the opportunity, they cannot afford it.

E5: There are children who are active and talented in many things and when parents decide thatmusic has less perspective and is not so BENEFICIAL for the future, that makes me sad.

E-3: That's the difference between Russian and Estonian schools: in our schools choir singing is not that popular. [....]...now there are about 100 participants in toddlers' choir - it was really unusual that so many--- so many came. Well, the choir culture is different of course, the level... well I don't know, all this listening to the concert and sitting still.... very hard to gain...

One Estonian teacher also mentioned the problem concerning perfect pitch and relative pitch match.

E3: Well, for me... the problem is that I have the perfect pitch. And the same is with such kids - youhave to transpose ...no very convenient.

\section{Conclusions}

The content of the interviews provided very interesting information as music teachers' pedagogical thinking has not been widely researched. Most of the teachers' thinking stays on the action level and is connected with the choice of music practices, solving different 
everyday problems. Still, there are several specific features that occur in music teaching context: problems with instructional devices, need of enough space for musical movement, various out-of-class practices: choir, band, ensembles; small number of lessons, just to name a few. Estonian teachers revealed the differences between Estonian and Russian speaking pupils and the socio-cultural understandings. The Finnish teachers mentioned the insufficient time for music studies in class teachers' training as well as not enough in-service training for music subject. This also explains the moderate knowledge and use of music teaching methods.

Quite positive is the notion that music teachers have a broader vision of the significance of music education: about the value and meaning of music education in pupils' lives and in the wider socio-cultural context.

Although at the first glance the themes seemed to place on a certain one level, there appeared interesting connections between all the three thinking levels: thinking on one level gives grounds and "starts" thinking on the next level. So there is an interconnection presented between all the three thinking levels.

This gives the grounds to re-think the scheme of the pedagogical thinking levels by Kansanen and offer another design for the model (figure 2).

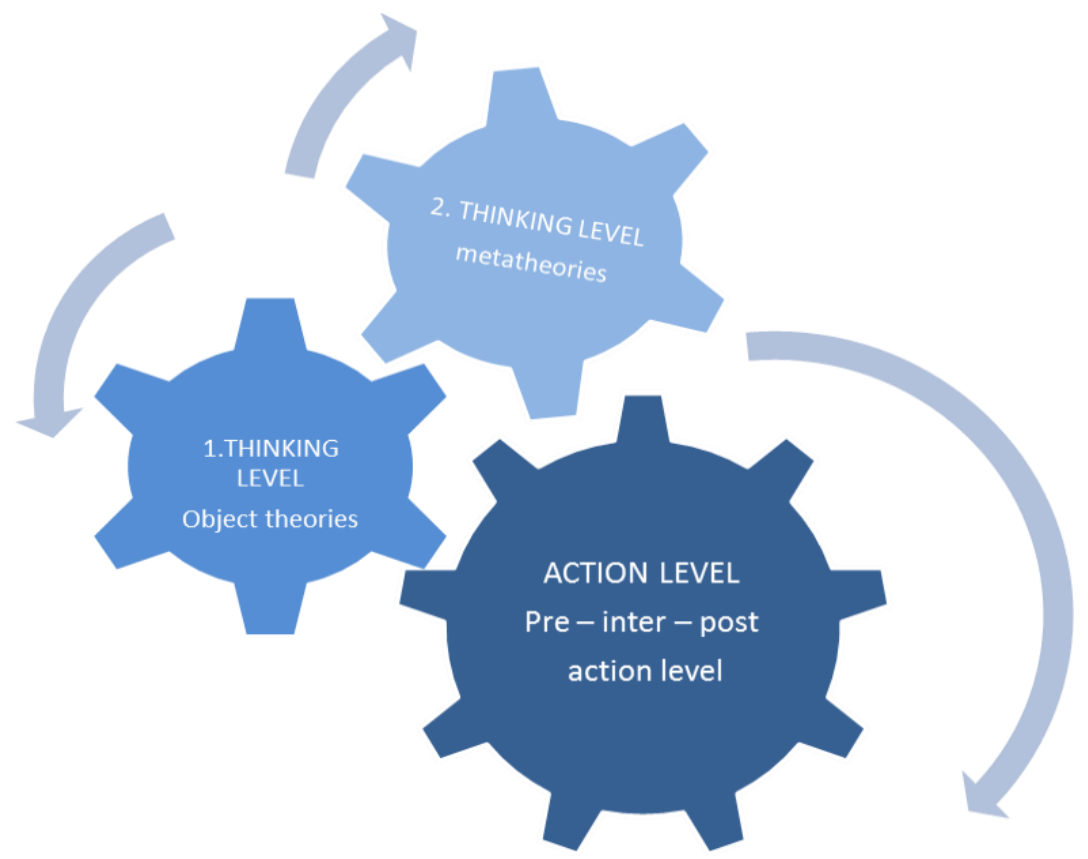

Figure 2. Sepp's applied model of pedagogical thinking after Kansanen 
Music teaching on comprehensive school level in Estonia and Finland has several similar features, especially concerning the music practices, the problems with resources and appreciation of music as school subject. Thus, as the socio-cultural grounds, historical development and teachers' education contain significant differences, there occur also differences in teachers' thinking and teaching practices.

Although the music syllabus in the National Curriculum gives the main directions to design music teaching, there are still various possibilities how the teacher plans and understands it in real teaching-learning situation. As every teacher is an individual and has her/his own understanding and approach to interpret this document, the decisions may vary a lot. This gives grounds to the next questions and research themes about the preferences and ethics of music teaching as well as the different factors influencing these topics.

\section{Acknowledgements}

The author(s) declare that there is no conflict of interest.

\section{References}

Aaltonen, K. (2003). Pedagoogisen ajattelun ja toiminnan suhde. Opetustaan integroivan opettajan tietoperusta lähihoitajakoulutuksessa. Joensuu: Joensuun yliopistopaino. [The Relationship Between Pedagogical Thinking and Action. Teacher's knowledge base in the context of integrated teaching in practical nurse education.] Joensuu: University of Joensuu. Publications in Education No. 89.

Cohen, Manion, Morrison. (2007). Research Methods in Education. New York, NY: Routledge. https://doi.org/10.4324/9780203029053

Eisner, E. W. (1993). Invitational Conference on the Hidden Consequences of a National Curriculum. Educational Researcher, 22(7), 38-39.

Elliott, D. J. (2009). Curriculum as Professional Action. In Music Education for Changing Times. https://doi.org/10.1007/978-90-481-2700-9_13

Galen Saylor, J., Alexander, W. M., \& Lewis, A. J. (1981). Curriculum Planning for Better teaching and Learning. New York, NY: Holt, Reinhart and Winston.

Hsieh, H.-F., \& Shannon, S. E. (2005). Three Approaches to Qualitative Content Analysis. Qualitative Health research, 15(9), 1277-1288. https://doi.org/10.1177/1049732305276687

Jones, H. (2008). Thoughts on teaching thinking: perceptions of practitioners with a shared culture of thinking skills education, Curriculum Journal, 19(4), 309-324. https://doi.org/10.1080/09585170802509898

Kansanen, P. (1991). Pedagogical thinking: The Basic Problem of Teacher education. European Journal of Education, 26(3), 251-260. https://doi.org/10.2307/1503027

Kansanen, P. (1993). An Outline for a Model of Teachers' Pedagogical Thinking. In P. Kansanen (Ed.), Discussions on Some Educational Issues IV (pp. 51-65). Research Report 121. Department of TeacherEducation, University of Helsinki. 
Kansanen, P., Tirri, K., Meri, M., Krokfors, L., Husu, J., \& Jyrhämä, R. (2000). Teachers' pedagogical thinking. Theoretical landscapes, practical challenges. New York, NY: Peter Lang. https://doi.org/10.3726/978-1-4539-1514-1

Künzli, R. (2000). Gernam Didaktik: Models of Re-presentation, of Intercourse, and of Experience. In Westbury et al (Eds.), Teaching as a Reflective practice. The German Didaktik Tradition (pp. 41-54). New York, NY: Routledge.

Munby, H. (1982). The Place of Teachers' Beliefs on Research on teacher Thinking and decision Making, and an Alternative methodology. Instructional Science, 11, 201225. https://doi.org/10.1007/BF00414280

Patrikainen, S. (2012). Luokanopettajan pedagoginen ajattelu ja toiminta matematiikan opetuksessa [Class teacher's pedagogical thinking and action in mathematics education]. Helsinki, University of Helsinki.

Regelski, T. A. (2009). Curriculum. In T. A. Regelski, \& T. J. Gates (Eds.), Music education for Changing Times. Dordrecht: Springer. https://doi.org/10.1007/978-90-481-2700-9

Ruus, V.-R. (2003). Õppekava kui ajaloovabrik [Curriculum as the history factory]. Haridus, 2, 4-9.

Shavelson, R. J., \& Stern, P. (1981). Research on Teachers' Pedagogical Thoughts, Judgments, Decisions, and Behavior. Review of Educational Research, 51(4), 455498. https://doi.org/10.3102/00346543051004455

Szönyi, E. (1974). Musical Reading and Writing. Budapest: Corvina Press.

Slattery, Patrick. (2006). Curriculum development in postmodern era. Routlegde, New York.

Syrjäläinen, E., Jyrhämä, R., Haverinen, L., \& Praktikumikäsikirja (2004). Studia Pædagogica 33. Retrieved on January 29, 2013, www.helsinki.fi/behav/praktikumikasikirja/kehyksetön

Toom, A. (2006). Tacit Pedagogical Knowing At the Core of Teacher's Professionality. Yliopistopaino, Helsinki.

van Manen, M. (1991). The Tact of Teaching. The meaning of pedagogical thoughtfulness. State University of New York Press.

Westbury, I., Hopmann, S., \& Riquarts, K. (2000). Teaching as a Reflective practice. The German Didaktik Tradition. New York, NY: Routledge. 